\title{
The Term Structure of Euromarket Interest Rates: An Empirical Investigation
}

\section{Citation}

Campbell, John Y., and Richard H. Clarida. 1987. The term structure of euromarket interest rates: An empirical investigation. Journal of Monetary Economics 19(1): 25-44.

\section{Published Version}

http://dx.doi.org/10.1016/0304-3932(87)90027-4

\section{Permanent link}

http://nrs.harvard.edu/urn-3:HUL.InstRepos:3353759

\section{Terms of Use}

This article was downloaded from Harvard University's DASH repository, and is made available under the terms and conditions applicable to Other Posted Material, as set forth at http:// nrs.harvard.edu/urn-3:HUL.InstRepos:dash.current.terms-of-use\#LAA

\section{Share Your Story}

The Harvard community has made this article openly available.

Please share how this access benefits you. Submit a story.

Accessibility 
NBER WORKING PAPER SERIES

THE TERM STRUCTURE OF EUROMARKET INTEREST RATES:

AN EMPIRICAL INVESTIGATION

John Y. Campbe 11

Richard H. Clarida

Working Paper No. 1946

NATIONAL BUREAU OF ECONOMIC RESEARCH

1050 Massachusetts Avenue

Cambridge, MA 02138

June 1986

We would like to thank Matt Shapiro, Russe 11 Cooper, Bob Cumby, Ken West, Bob Shiller, an anonymous referee, and seminar participants at the Cowles Foundation, NYU, Princeton, and the NBER Summer Institute, for helpful comments on an earlier draft. We, of course, are responsible for all remaining errors. We acknowledge support from the National Science Foundation, grants SES 85-11070 and SES 84-20227 respectively. The research reported here is part of the NBER's research programs in Financial Markets and Monetary Economics and International Studies. Any opinions expressed are those of the authors and not those of the National Bureau of Economic Research. 
The Term Structure of Euromarket Interest Rates:

An Empirical Investigation

\begin{abstract}
This paper is an empirical investigation of the predictability and comovement of risk premia in the term structure of Euromarket interest rates. We show that variables which have been used as proxies for risk premia on uncovered foreign asset positions also predict excess returns in Euromarket term structures, while variables which have been used as proxies for risk premia in the term structure also predict excess returns on taking uncovered foreign asset positions. These findings suggests that risk premia in the Euromarket term structures and on uncovered foreign asset positions move together. We test formally the hypothesis that risk premia on uncovered 3-month EuroDM and Eurosterling deposits move in proportion to a single latent variable. We are unable to reject this hypothesis. We are also unable to reject the hypothesis that the risk premia on these three strategies and those on rolling over 1-month Eurosterling (EuroDM) deposits versus holding a 3 -month Eurosterling (EuroDM) deposit move in proportion to a single latent variable. The single latent variable model can be interpreted atheoretically, as a way of characterizing the extent to which predictable asset returns "move together"; or it can be interpreted as in hansen and Hodrick (1983) and Hodrick and Srivastava (1983) as a specialization of the ICAPM in which assets have constant betas on a single, unobservable benchmark portfolio.
\end{abstract}

John Y. Campbe 11

Department of Economics

Dickinson Hall

Princeton University

Princeton, NJ 08544
Richard H. Clarida The Cowles Foundation Yale University Box 2125, Yale Station New Haven, CT 06520 
THE TERM STRUCTURE OF EUROMARKET INTEREST RATES:

AN EMPIRICAL INVESTIGATION

John Y. Campbell and Richard H. Clarida

\section{Introduction}

There is by now a substantial body of empirical work on the predictability of excess returns across assets of the same maturity denominated in different currencies. Recent studies by Geweke and Feige (1979), Hansen and Hodrick (1980, 1983), Cumby and Obstfeld (1981, 1982), Hakkio (1981a), and Hodrick and Srivastava (1983) have rejected the "Fisher open" hypothesis that interest rate differentials on assets of the same maturity denominated in different currencies are offset by an expected exchange rate depreciation and the hypothesis, equivalent given covered interest arbitrage, that forward exchange rates are efficient predictors of future spot rates. The source of these rejections is that information variables such as the percentage forward premium [Hodrick and Srivastava (1983)] or lagged forward rate forecast errors [Hansen and Hodrick (1980)] help to predict realized excess returns on uncovered foreign asset positions.

Hansen and Hodrick (1983) and Hodrick and Srivastava (1983) have tested whether or not the time varying risk premia which separate the dollar prices of 1 -month forward contracts in several currencies from expected future spot exchange rates are driven by a single latent variable. This latent variable 
is interpreted in the context of the intertemporal capital asset pricing model (ICAPM) as the expected dollar return on some benchmark portfolio in excess of the nominally riskless 1 -month dollar rate. ${ }^{1}$ Hansen and Hodrick (1983) were unable to reject the hypothesis that risk premia on 1 -month yen, mark, pound, Swiss franc, and French franc forward contracts all move in proportion to a single latent variable. By contrast, using a somewhat longer data series which included an additional twenty-one months of data ending in September 1982, Hodrick and Srivastava (1983) rejected the single latent variable model for the same five contracts. ${ }^{2}$

The expectations theory of the term structure of 'on shore' U.S. interest rates has also been rejected in recent empirical work. Shiller, Campbell, and Schoenholtz (1983) and Mankiw and Summers (1984) have shown that the spread between 6 - and 3 -month treasury bill rates has predictive power for excess returns in the U.S. term structure. Campbell (1985) has decisively rejected the hypothesis that the time varying risk premia on 2 -month treasury bills, bonds, and stocks over 1 -month bills all move in proportion to a single latent variable.

This paper is an empirical investigation of the predictability and comovement of risk premia in the term structure of Euromarket interest rates. Our approach may be described as follows. We choose the dollar as our numeraire currency and focus on four alternative strategies for obtaining dollar payoffs three months hence. The first is to purchase a 3-month Eurodollar deposit, a nominally riskless investment under our assumptions. The second is to roll over 1 -month Eurodollar deposits. The third is to purchase a 3-month foreign currency Eurodeposit and to sell the proceeds received three months hence at the then prevailing spot exchange rate. The 
fourth is to purchase a 1 -month foreign currency Eurodeposit, reinvest the proceeds in 1 -month Eurodeposits in the same currency, and to sell the proceeds accumulated after three months at the then prevailing spot exchange rate. The difference in ex post excess returns on the latter two strategies is equal to the realized foreign currency return on holding a 3 -month foreign currency Eurodeposit versus rolling over three 1-month deposits denominated in the same currency. Each of these latter three strategies generates a risky dollar payoff three months hence. We establish that the excess returns on these risky strategies relative to the 3-month Eurodollar deposit rate are predictable given information such as the spreads between 3- and 1-month Eurodeposit rates and the differentials between 3-month foreign currency Eurodeposit rates and the 3 -month Eurodollar rate. The main task of the paper is to test whether or not the time varying risk premia on each of these risky strategies move in proportion to a single latent variable. This hypothesis can be interpreted atheoretically, as a way of characterizing the extent to which predictable asset returns "move together"; or it can be interpreted as in Hansen and Hodrick (1983) and Hodrick and Srivastava (1983) as a specialization of the ICAPM in which assets have constant betas on a single, unobservable benchmark portfolio. The data are restricted in this framework with as few as two asset returns and two information variables.

The first contribution of this paper is to show that variables which have been used as proxies for risk premia on uncovered foreign asset positions also predict excess returns in at least two Euromarket term structures. In addition, variables which have been used as proxies for risk premia in the term structure also predict excess returns on taking uncovered 
foreign asset positions. These findings suggest that risk premia in the Euromarket term structures an on uncovered foreign asset positions move together. We first test the hypothesis that risk premia on uncovered 3-month EuroDM and Eurosterling deposits and on rolling over 1-month versus holding 3-month Eurodollar deposits move in proportion to a single latent variable. We are unable to reject this hypothesis at standard levels of significance. We next test whether or not the risk premia on these three strategies and those on rolling over l-month Eurosterling (EuroDM) deposits versus holding a 3 -month Eurosterling (EuroDM) deposits move in proportion to a single latent variable. Again, we are unable to reject this hypothesis at any reasonable level of significance.

The plan of the paper is as follows. Section II discusses the data series used and the construction and interpretation of the relevant excess return variables. This section also shows how we construct proxies for risk premia, and summarizes the behavior of these information variables over the sample period. Section III provides an overview of the estimation and testing strategies employed in the analysis. Section IV investigates the existence and nature of predictable excess returns in the Eurodollar term structure and on uncovered 3-month EuroDM and Eurosterling deposits. A formal test of the proportionality of these predictable excess returns with a single latent variable is presented. The section concludes with a similar investigation of the predictability and comovement of excess returns on these three strategies and those on rolling over l-month Eurosterling (EuroDM) deposits versus holding a 3 -month Eurosterling (EuroDM) deposit. Section $\mathrm{V}$ provides some concluding remarks. 


\section{Construction and Interpretation of Variables}

The data set used in this paper consists of weekly observations on DM and sterling spot exchange rates relative to the dollar, and on 1 - and 3-month Eurodollar, EuroDM, and Eurosterling deposit rates. ${ }^{3}$ From these data, we construct excess returns on three alternative investment strategies relative to a baseline investment in a 3-month Eurodollar deposit. Each alternative requires a dollar investment and yields a risky dollar payoff after three months.

The log of the 3 -month gross return on the baseline investment, undertaken at time $t$, is $\log \left(1+R_{3, t}\right.$ (us)/400) where $R_{3, t}$ (us) is the 3-month Eurodollar deposit rate quoted in percentage points per year at time $t$. In forming excess returns, we subtract log gross returns on alternative investments from the baseline and simplify by using the approximation $\log (1+x)=x .^{4}$ Finally we multiply by 400 to express excess returns in units of percentage points per year.

The first alternative investment strategy we consider is that of rolling over 3 successive 1-month Eurodollar deposits. The log gross return on this strategy is $\log \left[\left(1+R_{1, t}\right.\right.$ (us)/1200)( $1+R_{1, t+1}$ (us)/1200) $\cdot\left(1+R_{1, t+2}\right.$ (us)/1200)]. The approximate excess return on the baseline over the dollar rollover strategy, in percentage points per year, is

$$
\lambda_{t}^{(3,1)} \text { (us, us) }=R_{3, t} \text { (us) - (1/3) } \sum_{i=0}^{2} R_{1, t+i} \text { (us) }
$$

The rational expectation at time $t$ of this excess return is called the "rolling premium" on a 3-month Eurodollar deposit over 1-month Eurodollar deposits [Campbell and Shiller (1984)]. 5 According to the "pure expec- 
tations theory" of the term structure, the rolling premium is zero. A slightly weaker hypothesis, which we call the "expectations theory" and test in this paper, is that the rolling premium is constant through time at some (possibly nonzero) level.

The next set of alternative investments involves the purchase of a 3-month EuroDM or Eurosterling deposit. For example, dollars are used to purchase DM at time $t$; the DM are invested in a 3-month EuroDM deposit: and the DM proceeds are converted to dollars at the time $t+3$ spot exchange rate, which is uncertain at time $t \cdot{ }^{6}$ The log gross return on this strategy is

$$
\log \left[\left(1+R_{3, t}(g) / 400\right) S_{t+3}(g) / s_{t}(g)\right],
$$

where $s_{t}(g)$ is the dollar price of DM at time $t$. The approximate excess return on the baseline over the 3 -month DM strategy, in percentage points per year, is

$$
\lambda_{t}^{(3,3)} \text { (us,g) }=R_{3, t} \text { (us) }-R_{3, t}(g)-400\left[\log s_{t+3}(g)-\log s_{t}(g)\right]
$$

The "Fisher open" hypothesis (uncovered interest parity) states that the rational expectation of (2) at time $t$ is zero, or at least constant through time.

Finally, we consider mixed strategies which involve rolling over 1-month EuroDM or Eurosterling deposits. Returns on these strategies are uncertain both because future 1 -month Eurodeposit rates are uncertain, and because future spot exchange rates are uncertain. ${ }^{7}$ The $\log$ gross return on a mixed DM strategy is 
$\log \left[\left(1+R_{1, t}(g) / 1200\right)\left(1+R_{1, t+1}(g) / 1200\right)\left(1+R_{1, t+2}(g) / 1200\right) s_{t+3}(g) / S_{t}(g)\right]$.

The approximate excess return on the baseline over the mixed DM strategy, in percentage points per year, is

$\lambda_{t}^{(3,1)}$ (us,g) $=R_{3, t}$ (us)-(1/3) $\sum_{i=0}^{2} R_{1, t+i}(g)-400\left[\log s_{t+3}(g)-\log s_{t}(g)\right]$.

The difference between $\left(2^{\prime}\right)$ and $(2)$ is just the excess return in the DM term structure, the German equivalent of (1). In general we have,

$\lambda_{t}^{(3,1)}(j, j)=R_{3, t}(j)-(1 / 3) \sum_{i=0}^{2} R_{1, t+i}(j)-\lambda_{t}^{(3,1)}$ (us, j) $-\lambda_{t}^{(3,3)}$ (us, j), (3)

for $j$ - Germany, United Kingdom.

Recent theoretical work on asset pricing restricts the behavior of the excess returns defined in equations (1), (2) and (3). Formulated in discrete time with a representative agent with time separable utility u defined over consumption $c$, the intertemporal capital asset pricing models of Merton (1973), Lucas (1978, 1982), Breeden (1979), and Hansen, Richard, and Singleton (1981) imply that for any asset $i$, the gross dollar return from time $t$ to time $t+n, 1+h_{t}^{(n)}(i)$, must satisfy the first-order condition

$$
E_{t}\left[Q_{t, t+n}^{m}\left(1+h_{t}^{(n)}(i)\right)\right]-1
$$

Here $E_{\hat{t}}$ denotes expectation conditional on the representative agent's information set at time $t$, and $Q_{t, t+n}^{m}$ is the marginal rate of substitu- 
tion of dollars between $t+n$ and $t$. In a one good world and in the absence of cash-in-advance constraints

$$
Q_{t, t+n}^{m}=\frac{\delta^{n} U^{\prime}\left(c_{t+n}\right) P_{t}}{U^{\prime}\left(c_{t}\right) P_{t+n}}
$$

where $\delta$ is a discount factor and $P_{t}$ is the dollar price of the consumption good at date $t$ (Hansen and Hodrick (1983) and Mark (1985)). In a more complex model, with multiple goods or cash-in-advance constraints, equation (5) would have to be generalized but a relation of the form (4) would remain valid.

In our context, (4) implies that, for example,

$$
E_{t}\left[Q_{t, t+3^{\lambda}}^{m}{ }^{(3,1)} \text { (us, g) }\right]=0
$$

which is obtained by subtracting relation (4) for the DM rollover strategy from relation (4) for the baseline Eurodollar investment strategy.

Rearranging the expectation of the product into the sum of the covariance and the product of expectations, (6) implies

$$
E_{t}\left[\lambda_{t}^{(3,1)}(u s, g)\right]=\operatorname{cov}_{t}\left[Q_{t, t+3}^{m}, \lambda_{t}^{(3,1)}(u s, g)\right] / E_{t}\left[Q_{t, t+3}^{m}\right]
$$

Thus the risk premium is proportional to the conditional covariance of the intertemporal marginal rate of substitution of dollars and the excess dollar return on buying DM, rolling over 1-month EuroDM deposits, and selling the accumulated proceeds back for dollars at the exchange rate prevailing three months hence. The other risky returns studied in this paper are priced analogously in the ICAPM framework. 
Now consider a "benchmark" portfolio defined to have nominal return

$$
\left(1+h_{t}^{(3)}(b)\right)=Q_{t, t+3}^{m} / E_{t}\left[\left(Q_{t, t+3}^{m}\right)^{2}\right] .
$$

Clearly, for any asset i

$$
E_{t}\left[\left(1+h_{t}^{(3)}(b)\right)\left(1+h_{t}^{(3)}(i)\right)\right]=1 / E_{t}\left[\left(Q_{t, t+3}^{m}\right)^{2}\right]
$$

The nominally riskless rate must obey $\left(1+R_{3, t}(u s)\right)=1 / E_{t}\left[Q_{t, t+3}^{m}\right]$, so that

$$
E_{t}\left[\left(1+h_{t}^{(3)}(b)\right)\left(1+h_{t}^{(3)}(i)\right)\right]-\left(1+R_{3, t}(\text { us })\right) E_{t}\left(1+h_{t}^{(3)}(b)\right)
$$

This can be rewritten as

$$
R_{3, t} \text { (us) }-E_{t}\left[h_{t}^{(3)}(i)\right]=\operatorname{cov}_{t}\left[h_{t}^{(3)}(i), h_{t}^{(3)}(b)\right] / E_{t}\left[\left(1+h_{t}^{(3)}(b)\right)\right] \text {. }
$$

This relationship must hold for $h_{t}^{(3)}(i)=h_{t}^{(3)}(b)$, so we can substitute out $E_{t}\left[1+h_{t}^{(3)}(b)\right]$ to obtain

$$
R_{3, t} \text { (us) }-E_{t}\left[h_{t}^{(3)}(i)\right]=\beta_{i t}\left[R_{3, t}(u s)-E_{t} h_{t}^{(3)}(b)\right]
$$

or in more compact notation,

$$
E_{t}\left[\lambda_{t}^{(3)}(i)\right]=\beta_{i t} E_{t}\left[\lambda_{t}^{(3)}(b)\right]
$$

where $\beta_{i t}=\operatorname{cov}_{t}\left[h_{t}^{(3)}(i), h_{t}^{3}(b)\right] / \operatorname{var}_{t}\left[h_{t}^{3}(b)\right]=\operatorname{cov}_{t}\left[\lambda_{t}^{(3)}(i)\right.$, $\left.\lambda_{t}^{(3)}(b)\right] / \operatorname{var}_{t}\left[\lambda_{t}^{(3)}(b)\right]$. Thus, the expected dollar excess return on asset $i$ is proportional to the expected excess return on a benchmark portfolio whose payoff is perfectly conditionally correlated with the intertemporal 
marginal rate of substitution of dollars. Although the betas $\beta_{i t}$ can in general vary over time, our econometric work will test restrictions implied by constant betas. As pointed out by Hansen and Hodrick (1983), such tests are not tests of a fully specified general equilibrium model, but are tests of proportional co-movement of expected excess returns which are motivated by the ICAPM.

In Section IV, we test the hypotheses that the rational expectations of excess returns are constant through time by regressing excess returns on a constant and "information variables" which are known at time $t$, and testing the joint significance of the information variable coefficients.

If such tests are to be powerful against a broad range of alternatives, the information variables used should be ones which plausibly predict excess returns when the expectations and Fisher open hypotheses are false. Some authors have used lagged excess returns [Hansen and Hodrick (1980)], thereby conducting a "weak-forn" test. We adopt a different approach, using as information variables elements of excess returns themselves, as defined in equations (1), (2) and (3), which are known at time $t$.

The element of ( 1 ) which we use for our tests is $R_{3, t}$ (us) $-R_{1, t}$ (us), the spread between 3 -month and 1 -month Eurodollar interest rates. Using the linear approximation for the term structure, the Eurodollar spread can be decomposed into

$$
\begin{aligned}
R_{3, t} \text { (us) }-R_{1, t} \text { (us) }= & E_{t} \lambda_{t}^{(3,1)} \text { (us,us) }+\frac{2}{3}\left[E_{t} R_{1, t+1} \text { (us) }-R_{1, t} \text { (us) }\right] \\
& +\frac{1}{3}\left[E_{t} R_{1, t+2} \text { (us) }-E_{t} R_{1, t+1} \text { (us) }\right]
\end{aligned}
$$


When the expectations theory of the term structure holds, the first term on the right hand side of (13) is a constant; unusually high longer term interest rates are then due entirely to expectations of short rate increases. However if there is any variation in the rolling premium, it will be reflected in the spread so that this variable should be a good instrument for our empirical work.

The element of (2) we use is $R_{3, t}$ (us) $-R_{3, t}(j)$, the interest differential between 3 -month Eurodollar and EuroDM and Eurosterling rates. 8 Following Fama (1984), we can decompose this variable into the sum of the cross-currency risk premium, and the expected rate of depreciation of the dollar relative to currency $j$ :

$R_{3, t}$ (us) $-R_{3, t}(j)-E_{t} \lambda_{t}^{(3,3)}(u s, j)+400\left[E_{t} \log s_{t+3}(j)-\log s_{t}(j)\right]$

When uncovered interest parity holds, the first term on the right hand side of (14) is constant, and unusually high differentials are then due entirely to expected dollar depreciation. However in general variation in the crosscurrency risk premium will be reflected in the differential, so this is also a good instrument for our purposes.

One final set of information variables corresponds to equation (3). We include foreign currency term structure spreads, $R_{3, t}(j)-R_{1, t}(j)$, which can be decomposed in the manner of equation (13). ${ }^{9}$

If our tests are to be powerful, it is also desirable that our information variables should not be too highly correlated. The inclusion of variables which are highly collinear with other instruments is likely to use up degrees of freedom in estimation and testing, without contributing to the predictability of returns. To check for this, and to review the behavior of 
interest rates over our sample, we present summary statistics for information variables in Table 1.

The first row of Table 1 reports the mean Eurodollar spread, the mean differentials between 3-month Eurodollar and foreign currency rates, and the mean foreign currency spreads. Mean spreads in all currencies are positive but small, ranging from just over 5 basis points in the UK to almost 13 basis points in Germany. The mean Eurodollar rate is more than 420 basis points higher than the mean EuroDM rate, but almost 175 basis points lower than the mean Eurosterling rate. The second row of Table 1 reports standard deviations, which are all quite large relative to the means. 10

The bottom panel of Table 1 shows the correlations of the various instruments. The highest correlation, 0.646 , is between the two differentials; evidently movements in US interest rates relative to the other two currencies account for a large part of the variation in the differentials. There are positive but fairly small correlations among the spreads in all three currencies. None of the correlations are high enough to suggest that we should drop any of our information variables.

\section{Econometric Issues}

Most of the empirical work of this paper is conducted within a standard regression framework. The major econometric difficulty in our application is one which is by now familiar from the work of Hansen and Hodrick (1980) and others; we have weekly observations but a 3-month (13-week) holding period, so the error terms in our regressions follow an MA-12 process under the null hypothesis. 11 
Serial correlation in the equation error does not affect the consistency of OLS coefficient estimates, $\hat{b}_{T}$, but it does require an adjustment in the estimated variance-covariance matrix of these estimates. Hansen and Hodrick (1980), following Hansen (1979), propose the following consistent estimator of the variance-covariance matrix of $\sqrt{\mathrm{T}}\left(\hat{b}_{\mathrm{T}}-\mathrm{b}_{\mathrm{T}}\right)$ :

$$
\hat{\theta}=T\left(X_{T} X_{T}\right)^{-1} X_{T}^{\prime} \hat{\Omega}_{T} X_{T}\left(X_{T}^{\prime} X_{T}\right)^{-1}
$$

Here $X_{T}$ is the matrix of independent variables at sample size $T$, and the $(i, j)^{\text {th }}$ element of $\hat{\Omega}_{T}, \omega_{T}(i, j)$, is defined by

$$
\begin{array}{rlrl}
\hat{\omega}_{T}(i, j) & =(1 / T) \sum_{t-k+1}^{T} \hat{u}_{t} \hat{u}_{t-k} & \text { for } k \leq n, \\
& =0 & & \text { otherwise, }
\end{array}
$$

where $k-|i-j|$ and $n-12$ (the order of the MA process).

The above estimator does not allow for conditional heteroskedasticity in the error term, but it is straightforward to do so, using the method of White (1984) and following Hsieh (1984) and Cumby and Obstfeld (1984), by redefining $\hat{\omega}_{T}(i, j)-\hat{u}_{i} \hat{u}_{j}$ for $k \leq n$ and $=0$ otherwise.

One problem with both Hansen and Hodrick's estimator and its heteroskedasticity-consistent variant, is that $\hat{\Omega}_{T}$ need not be positive definite in finite samples. Thus use of $\hat{\theta}$ in practice may result in negative "Chi-squared" test statistics or even negative standard errors; problems may also arise with nonlinear iterative estimation methods of the type we use to estimate the latent variable models.

Newey and West (1985) propose a simple modification of $\hat{\Omega}_{T}$ which is consistent and constructed to be positive definite. Allowing for condi- 
tional heteroskedasticity, this is $\hat{\omega}_{T}(i, j)=\gamma(k, m) \hat{u}_{i} \hat{u}_{j}$ for $k \leq m$; and $=0$ otherwise, where $\gamma(k, m)=1-(k /(m+1))$ and $m \rightarrow \infty$ as $T \rightarrow \infty$, but no faster than the fourth root of $T$.

Newey and West's estimator achieves positive definiteness by downweighting the higher-order autocovariances of $\hat{u}_{T}$, and consistency by reducing the downweighting as $T$ increases. We were conservative in applying this estimator, choosing $m=2 n$ for our fixed sample size so that the first 12 autocovariances-those which are nonzero under the null--all received weights of at least $1 / 2$. In general, for this choice of $m$, Newey and West's estimator gave us standard errors which were at least as large as any of the alternatives discussed above. ${ }^{12}$

When we come to estimate restricted single latent variable models, we use the Generalized Method of Moments procedure (Hansen (1982), Hansen and Singleton (1982)), which allows for the presence of conditional heteroskedasticity. This is important because in the ICAPM variations in expected returns on the benchmark portfolio will generally be associated with variations in the conditional covariance matrix of excess returns. We use Hansen's Chi-square statistic to test the nonlinear cross-equation restrictions of the model. We again employ Newey and West's procedure to construct the optimal weighting matrix for the GMM estimation.

\section{Empirical Results}

Tables 2, 3, and 5 present regression results which establish the predictability of excess returns in the Eurodollar term structure and on uncovered investments in 3-month EuroDM and Eurosterling deposits. The sample period is 1976:1 through 1982:52. The top half of Table 1 shows that 
these excess returns do not exhibit first-order serial correlation, thus passing the simplest "weak form" efficient markets test. 13 However, as indicated in the bottom half of Table 2, the spread between the 3 - and l-month Eurodollar rate has significant explanatory power for realized excess returns in the Eurodollar term structure, and the spread between the 3-month Eurodollar rate and the 3 -month Eurosterling rate (to a close approximation, the percentage forward premium on sterling) helps predict realized excess returns on uncovered 3 -month Eurosterling deposits. Similar findings are reported in Hakkio and Leiderman (1984) who test, and reject, the hypothesis that expected excess returns in the Eurodollar, EuroDM, and Eurosterling markets are constant.

More interesting are the results of Table 3. The top row demonstrates that the spreads between the 3-month Eurodollar rate and the 3-month EuroDM and Eurosterling rates jointly have incremental predictive content for excess returns in the Eurodollar term structure after allowing for the information contained in the spread between the 3-and 1-month Eurodollar rate. The bottom row of Table 3 shows that the spread between the 3 -month and 1-month Eurodollar rate has significant explanatory power for realized excess returns on uncovered Eurosterling deposits as do the differentials between the 3-month Eurodollar rate and the 3-month EuroDM and Eurosterling deposit rates. Tables 2 and 3 also indicate that none of the aforementioned variables predict realized excess returns on uncovered EuroDM deposits. However, as shown in the second row of Table 5, the spreads between 3 - and 1 -month EuroDM and Eurosterling deposit rates both have significant explanatory power for excess returns on uncovered 3 -month EuroDM deposits. To summarize, variables which have been used as proxies for risk 
premia on uncovered foreign asset positions also predict excess returns in the Eurodollar term structure, while variables which have been used as proxies for risk premia in the term structure also predict excess returns on taking uncovered foreign asset positions.

These findings suggest that risk premia in the Eurodollar term structure and on uncovered foreign asset positions move together. We now test formally the hypothesis that risk premia on uncovered 3-month EuroDM and Eurosterling deposits and on rolling over 1 -month versus holding 3-month Eurodollar deposits move in proportion to a single latent variable.

As discussed in Section II, the ICAPM places the following restrictions on the excess return of a particular asset $i$ :

$$
E\left[\lambda_{t}^{(3)}(i) \mid x_{t}\right]-\beta_{i} E\left[\lambda_{t}^{(3)}(b) \mid x_{t}\right]
$$

This equation is derived by projecting equation (12) onto a k-vector $x_{t}$ of information variables, a subset of the market's full information set. The first element of $x_{t}$ is just a constant. $\beta_{i}$ is the "beta" of excess return $i$ with the benchmark portfolio, defined as in equation (12) but now assumed to be constant through time. Since the expected excess return on the benchmark portfolio is unobservable, we substitute the best linear projection of this excess return on the variables in $x_{t}$, i.e.,

$$
E\left[\lambda_{t}^{(3)}(b) \mid x_{t}\right]-a^{\prime} x_{t}
$$

Consider now the implications of (16) and (17) for the system of $p$ regression equations

$$
\lambda-\Phi x_{t}+v_{t}
$$


where $\lambda$ is a p-vector of excess returns, $\Phi$ is a $p$ by $k$ matrix of regression coefficients with typical element $\phi_{i j}$, and $v_{t}$ is a p-vector of forecast errors which is orthogonal to $x_{t}$.

The model (16) and (17) imposes a single latent variable structure on (18), restricting $\phi_{i j}=\beta_{i} \alpha_{j}, \beta_{1}$ is normalized to unity so the first row of $\Phi$ estimates the $\alpha$ coefficients, the first column estimates the other $\beta$ coefficients and the lower right hand block is restricted. Thus there are $(p-1)(k-1)$ restrictions, which force expected excess returns on all assets to move in proportion with one another.

Table 4 presents parameter estimates of the $\alpha^{\prime} s$ and $\beta^{\prime} s$ and the test statistic for the hypothesis that the restrictions on $\phi_{i j}$ apply to the system of regression equations in Table 3. The information variables $x_{t}$ are a constant, the spread between the 3 - and 1-month Eurodollar rate and the spreads between the 3-month Eurodollar rate and the 3-month EuroDM and Eurosterling rates. The restrictions of the single latent variable model cannot be rejected at any reasonable level of significance: a $\chi^{2}(6)$ value of at least 7.323 would occur 29.28 of the time under the null.

Close inspection of Tables 2 and 3 reveals why we obtain this result. The key excess returns are $\lambda_{t}^{(3,1)}$ (us,us) and $\lambda_{t}^{(3,3)}$ (us,uk) which are predictable in Table 3 . The $\alpha$ coefficients in Table 4 are quite close to the unconstrained regression coefficients of $\lambda_{t}^{(3,1)}$ (us,us) in the first row of Table 3. The constrained system must then fit $\lambda_{t}^{(3,3)}$ (us,uk) to this vector of coefficients, multiplied by some scalar. The choice of $\beta_{3}=-1.193$ generates a vector of coefficients for $\lambda_{t}^{(3,3)}$ (us,uk) which has the same sign pattern as the unconstrained coefficients, although a 
smaller magnitude. The system estimates the $\alpha$ coefficients quite precise$1 y$, but the standard errors of the $\beta^{\prime} s$ are large relative to their point estimates. 14

Table 4 also reports the correlations of the estimated latent variable with each of the instruments. Even though the latent variable has been arbitrarily normalized by setting $\beta_{1}=1$, the same correlations (up to a possible sign change) would be obtained by any other normalization given the estimated coefficients of Table 4. The estimated latent variable is most strongly correlated with the Eurodollar spread, at 0.697 , but is also quite highly correlated with the two differentials.

In Tables 5 to 7 we repeat the above analysis for a large system of excess returns and information variables. The vector of excess returns is expanded to include the foreign term structure excess returns $\lambda^{(3,1)}(g, g)$ and $\lambda^{(3,1)}(u k, u k)$. We work with these excess returns, rather than the excess returns on "mixed" investment strategies defined in equation (2'), for several reasons. First, the foreign term structure excess returns are more directly comparable with excess returns in the domestic term structure. Secondly, the variance of exchange rate changes, and therefore of crosscurrency excess returns, is much greater than the variance of 1 -month interest rate changes which lead to term structure excess returns. (This can be seen in the table of summary statistics following Table 5.) When the two types of excess return are combined in a "mixed" excess return, the crosscurrency excess return dominates; $\lambda_{t}^{(3,1)}$ (us,j) and $\lambda_{t}^{(3,3)}$ (us,j) are almost perfectly collinear. Finally, even though the foreign term structure excess returns are not excess returns on dollar investments relative to a dollar benchmark, they are the differences between two dollar excess returns 
and thus, under the null hypothesis, obey the linear restrictions implied by the single latent variable model stated above.

Corresponding to the foreign term structure excess returns, we now include foreign term structure spreads in our vector of information variables along with the dollar spread and the cross-currency interest differentials.

Regression results for the larger system are presented in Table 5. The two new information variables have considerable explanatory power for cross-currency excess returns on 3-month Eurodeposits, so that the excess return on the 3 -month EuroDM investment strategy is now predictable along with the other excess returns. The excess return in the EurodM term structure is highly predictable; by contrast the expectations theory of the term structure cannot be rejected in the Eurosterling term structure. In general there appear to be important cross-effects which suggest that once again a single latent variable model might fit the data well.

In Table 6 we test and are unable to reject the hypothesis that a single latent variable explains the results of Table 5. Once again the coefficients are estimated precisely relative to the $\beta$ coefficients, but the point estimates of the $\beta^{\prime}$ s generally imply reduced-form regression coefficients which match the sign pattern of the most significant unconstrained coefficients. The new $\beta$ coefficients for foreign term structure spreads are estimated quite close to unity, although these estimates seem to be somewhat sensitive to the choice of starting values for the GMM procedure.

Finally, in Table 7 we shrink the model to the first three rows of Table 5, in order to compare the results with those of Table 4 which used 
the same set of excess returns, and in order to check the robustness of the latent variable model to changes in the estimated system. Once again the model seems to fit the data quite well; higher test statistics would be obtained under the null 19.58 of the time. In both Tables 5 and 6 the estimated latent variable continues to have a high correlation of around 0.7 with the Eurodollar spread.

\section{Conclusion}

In this paper we document the existence of predictable time-varying excess returns on a variety of investment strategies, relative to a 3-month Eurodollar investment. The strategies we consider involve three currencies - the dollar, the DM and the pound sterling--and two maturities--3- and 1-month Eurodeposits.

We find not only that excess returns are predictable, but that there are important cross-effects. Variables which traditionally are used to predict term structure excess returns also have explanatory power for cross-currency excess returns, and vice versa. In fact a tightly specified model, constraining all expected excess returns to move in proportion with a single latent variable, cannot be rejected at any reasonable significance level in a variety of tests. The estimated latent variable is quite highly correlated with the spread between 3- and 1-month Eurodollar interest rates.

Our favorable results for the single latent variable model contrast with the rejections reported by Campbell (1985) for US domestic assets and by Hodrick and Srivastava (1984) for Eurocurrency assets. However Gibbons and Ferson (1985) and Hansen and Hodrick (1983), working with domestic and Eurocurrency data respectively, also failed to reject the model. An 
important topic for future research is to sort out these apparently conflicting results. It does seem to be the case that rejections occur when more heterogeneous assets are studied, and when a longer sample period is used. Slow changes through time in relative betas of assets with widely divergent characteristics might explain this pattern of results. Our work should not be taken to imply that betas are constant for all assets in all sample periods, but merely as evidence that a simple latent variable structure describes our data.

These results are preliminary to a more structural investigation of the sources of predictable excess returns across currencies and maturities. If indeed predictable excess returns are driven by a single underlying latent variable, it seems plausible that conditional second moments of returns also move with this variable. We hope to explore the interrelationship between conditional first and second moments of returns in future work. 
TABLE 1

Summary Statistics for Information Variables

$$
\begin{array}{lll}
R_{3, t} \text { (us) }-R_{1, t} \text { (us) } & R_{3, t} \text { (us) }-R_{3, t}(j) & R_{3, t}(j)-R_{1, t}(j) \\
j=\text { ger } j=u k & j=\text { ger } j=u k
\end{array}
$$

$\begin{array}{lrrrrr}\text { Means } & 0.114 & 4.213 & -1.743 & 0.128 & 0.054 \\ \begin{array}{l}\text { Standard } \\ \text { Deviations }\end{array} & 0.523 & 2.415 & 3.912 & 0.219 & 0.612 \\ & & & & & \\ \text { Correlations: } & & & & & \\ \text { R(us)-R(us) } & 1.000 & 1.000 & & \\ \text { R(us)-R(ger) } & -0.130 & 0.646 & 1.000 & \\ \text { R(us)-R(uk) } & -0.084 & 0.211 & -0.029 & 1.000 & \\ \text { R(ger)-R(ger) } & 0.168 & 0.091 & 0.186 & 0.198 & 1.000 \\ \text { R(uk)-R(uk) } & 0.332 & & & \end{array}$

Note: The sample period for this table is 1976:1 through 1982:52. 
TABLE 2

$$
\lambda_{t}^{(3, n)}(u s, j)=a_{j}+b_{j} \lambda_{t-3}^{(3, n)}(u s, j)+u_{3, t}^{j}
$$

\begin{tabular}{|c|c|c|c|c|}
\hline Excess return & $\begin{array}{c}\hat{a}_{j} \\
(s . e .)\end{array}$ & $\begin{array}{c}\hat{b}_{j} \\
(s . e .)\end{array}$ & $\hat{\mathrm{b}}_{j}=0$ & $R^{2}$ \\
\hline$\lambda_{t}^{(3,1)}$ (us, us) & $\begin{array}{l}.085 \\
(.177) \\
(.631)\end{array}$ & $\begin{array}{l}-.124 \\
(.114) \\
(.277)\end{array}$ & 1.195 & .016 \\
\hline$\lambda_{t}^{(3,3)}$ (us, g) & $\begin{array}{c}3.001 \\
(3.389) \\
(.376)\end{array}$ & $\begin{array}{l}.126 \\
(.203) \\
(.535)\end{array}$ & .385 & .016 \\
\hline$\lambda_{t}^{(3,3)}$ (us, uk) & $\begin{array}{r}1.529 \\
(3.765) \\
(.685)\end{array}$ & $\begin{array}{l}.218 \\
(.156) \\
(.162)\end{array}$ & 1.950 & .046 \\
\hline
\end{tabular}

$$
\lambda_{t}^{(3, n)}(u s, j)-a_{j}+b_{j}\left(R_{3, t}(u s)-R_{n, t}(j)\right)+u_{3, t}^{j}
$$

\begin{tabular}{lcccc}
\hline$\lambda_{t}^{(3,1)}$ (us, us) &. .001 & $.664 *$ & $8.771 *$ & .076 \\
& $(.136)$ & $(.224)$ & & \\
$\lambda_{t}^{(3,3)}$ (us, g) & $(.994)$ & $(.003)$ & & .032 \\
& -3.336 & 1.606 & 1.974 & \\
$\lambda_{t}^{(3,3)}$ & $(5.345)$ & $(1.143)$ & & .133 \\
& $(.533)$ & $(.160)$ & & \\
& 5.688 & $2.225 *$ & $6.780 *$ & \\
& $(4.676)$ & $(.855)$ & & \\
\hline
\end{tabular}

Note: In this and all subsequent tables, a * indicates a significance level of at least 58. Below each coefficient, we report a heteroskedasticityconsistent standard error and the corresponding significance level. The sample period in all regressions is 1976:1 through 1982:52. 
TABLE 3

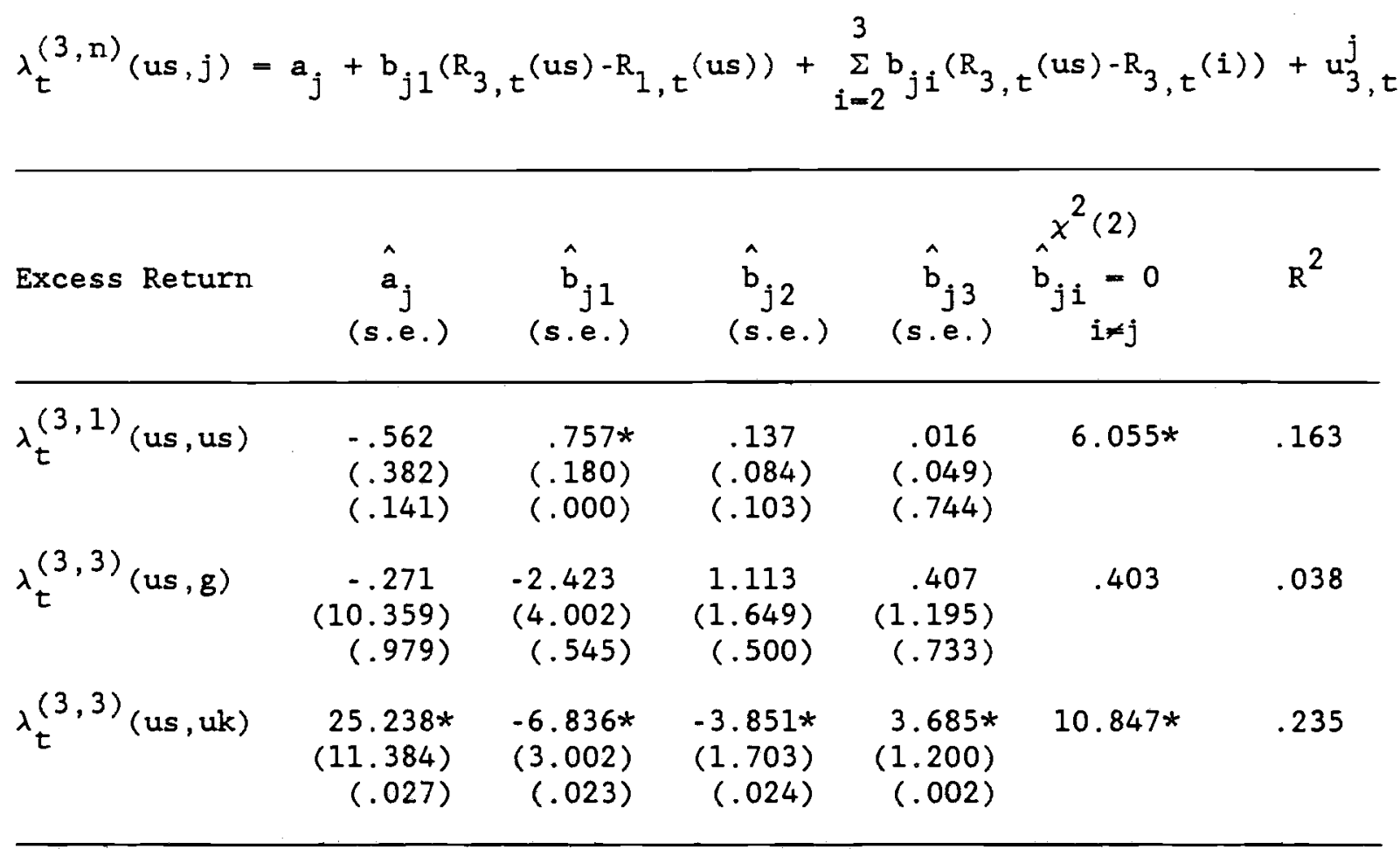

Summary Statistics

$$
\lambda_{t}^{(3,1)} \text { (us, us) } \quad \lambda_{t}^{(3,3)} \text { (us,g) } \quad \lambda_{t}^{(3,3)} \text { (us, uk) }
$$

Ex post Excess Returns:

\begin{tabular}{|c|c|c|c|c|}
\hline \multicolumn{2}{|l|}{ Means } & .074 & 3.430 & 1.008 \\
\hline \multicolumn{2}{|c|}{ Standard Deviations } & 1.262 & 21.746 & 23.850 \\
\hline Correlations: & $\begin{array}{l}\lambda \text { (us, us) } \\
\lambda \text { (us, g) } \\
\lambda \text { (us, uk) }\end{array}$ & $\begin{array}{l}1.000 \\
-.314 \\
-.149\end{array}$ & $\begin{array}{r}1.000 \\
1.000 \\
.492\end{array}$ & 1.000 \\
\hline
\end{tabular}

Ex ante Excess Returns:

\begin{tabular}{|c|c|c|c|c|}
\hline Means & & .074 & 3.430 & 1.808 \\
\hline Standard Devi & tions & .509 & 4.250 & 11.566 \\
\hline Correlations: & $\begin{array}{l}\lambda \text { (us, us) } \\
\lambda \text { (us, g) } \\
\lambda \text { (us, uk) }\end{array}$ & $\begin{array}{r}1.000 \\
.375 \\
-.120\end{array}$ & $\begin{array}{r}1.000 \\
.400\end{array}$ & 1.000 \\
\hline
\end{tabular}


TABLE 4

Latent Variable Estimates

(Based upon the three variable system in Table 2)

\begin{tabular}{|c|c|}
\hline$\alpha_{0}$ & $\begin{array}{r}-0.532 * \\
(.251) \\
(.034)\end{array}$ \\
\hline$\alpha_{1}$ & $\begin{array}{l}0.859 * \\
(.127) \\
(.000)\end{array}$ \\
\hline$\alpha_{2}$ & $\begin{array}{l}0.140 * \\
(.064) \\
(.029)\end{array}$ \\
\hline$\alpha_{3}$ & $\begin{array}{l}0.026 \\
(.034) \\
(.444)\end{array}$ \\
\hline$\beta_{1}$ & 1.000 \\
\hline$\beta_{2}$ & $\begin{array}{c}2.248 \\
(2.567) \\
(.381)\end{array}$ \\
\hline$\beta_{3}$ & $\begin{array}{r}-1.193 \\
(3.715) \\
(.748)\end{array}$ \\
\hline
\end{tabular}

Correlations of estimated latent variable with instruments:

$\begin{array}{ll}R \text { (us) - R(us) } & 0.697 \\ R \text { (us) - R(ger) } & 0.607 \\ R \text { (us) - R(uk) } & 0.497\end{array}$

Value of $\chi^{2}(6): 7.323$; significance level: .292. The initial values of the $\alpha$ 's are the point estimates in the first row of Table 3 ; initial values for the $\beta^{\prime} s$ are unity. Note: point estimates of some $\alpha^{\prime} s$ and $\beta^{\prime} s$ depend upon choice of initial values; the $\chi^{2}$ statistic is not materially affected by this choice. 
TABLE 5

$$
\begin{aligned}
\lambda_{t}^{(3, n)}(u s, j)=a_{j} & +b_{j 1}\left(R_{3, t}(u s)-R_{1, t}(u s)\right)+\sum_{i=2}^{3} b_{j i}\left(R_{3, t}(u s)-R_{3, t}(i)\right) \\
& +\sum_{i=2}^{3} b_{j, i+2}\left(R_{3, t}(i)-R_{1, t}(i)\right)+u_{3, t}^{j}
\end{aligned}
$$

\begin{tabular}{|c|c|c|c|c|c|c|c|c|}
\hline Excess Return & $\begin{array}{l}\hat{a}_{j} \\
\text { (s.e.) }\end{array}$ & $\begin{array}{l}\hat{b}_{j 1} \\
\text { (s.e.) }\end{array}$ & $\begin{array}{l}\hat{b}_{j 2} \\
\text { (s.e.) }\end{array}$ & $\begin{array}{l}\hat{b}_{j 3} \\
\text { (s.e.) }\end{array}$ & $\begin{array}{l}\hat{b}_{j 4} \\
\text { (s.e.) }\end{array}$ & $\begin{array}{l}\hat{\mathrm{b}}_{\mathrm{j5}} \\
\text { (s.e.) }\end{array}$ & $\begin{array}{c}x^{2}(4) \\
\hat{b}_{j i}=0 \\
i \neq j\end{array}$ & $R^{2}$ \\
\hline$\lambda_{t}^{(3,1)}$ (us,us) & $\begin{array}{l}-.524 \\
(.387) \\
(.176)\end{array}$ & $\begin{array}{l}.753 * \\
(.223) \\
(.001)\end{array}$ & $\begin{array}{l}.120 \\
(.084) \\
(.153)\end{array}$ & $\begin{array}{l}.026 \\
(.049) \\
(.596)\end{array}$ & $\begin{array}{l}.463 \\
(.462) \\
(.316)\end{array}$ & $\begin{array}{l}-.085 \\
(.192) \\
(.658)\end{array}$ & 6.88 & .169 \\
\hline$\lambda_{t}^{(3,3)}$ (us,g) & $\begin{array}{r}-1.297 \\
(9.801) \\
(.895)\end{array}$ & $\begin{array}{c}4.251 \\
(2.449) \\
(.083)\end{array}$ & $\begin{array}{r}2.093 \\
(1.657) \\
(.207)\end{array}$ & $\begin{array}{r}.368 \\
(1.246) \\
(.768)\end{array}$ & $\begin{array}{r}-26.023 * \\
(8.016) \\
(.001)\end{array}$ & $\begin{array}{r}-10.898 * \\
(2.706) \\
(.000)\end{array}$ & $36.449+$ & .202 \\
\hline$\lambda_{t}^{(3,3)}$ (us, uk) & $\begin{array}{r}25.384 * \\
(10.719) \\
(.018)\end{array}$ & $\begin{array}{r}-2.964 \\
(2.350) \\
(.207)\end{array}$ & $\begin{array}{r}-3.622 * \\
(1.683) \\
(.031)\end{array}$ & $\begin{array}{r}3.865 * \\
(1.202) \\
(.001)\end{array}$ & $\begin{array}{r}-6.224 \\
(7.501) \\
(.407)\end{array}$ & $\begin{array}{r}-8.176 * \\
(3.166) \\
(.010)\end{array}$ & $20.667 x$ & .279 \\
\hline$\lambda_{t}^{(3,1)}(g, g)$ & $\begin{array}{l}.454 * \\
(.091) \\
(.000)\end{array}$ & $\begin{array}{l}.174 * \\
(.062) \\
(.005)\end{array}$ & $\begin{array}{l}-.080 * \\
(.019) \\
(.000)\end{array}$ & $\begin{array}{l}.035 * \\
(.013) \\
(.007)\end{array}$ & $\begin{array}{l}.199 \\
(.137) \\
(.146)\end{array}$ & $\begin{array}{l}.118 \\
(.071) \\
(.097)\end{array}$ & $36.594 x$ & .216 \\
\hline$\lambda_{t}^{(3,1)}(\mathrm{uk}, \mathrm{uk})$ & $\begin{array}{l}-.234 \\
(.327) \\
(.474)\end{array}$ & $\begin{array}{l}.031 \\
(.215) \\
(.885)\end{array}$ & $\begin{array}{l}.046 \\
(.050) \\
(.358)\end{array}$ & $\begin{array}{l}-.045 \\
(.032) \\
(.160)\end{array}$ & $\begin{array}{l}-.079 \\
(.383) \\
(.837)\end{array}$ & $\begin{array}{l}.068 \\
(.223) \\
(.760)\end{array}$ & 3.369 & .018 \\
\hline
\end{tabular}

\begin{tabular}{|c|c|c|c|c|c|}
\hline & 1) (us,us) & $\lambda_{t}^{(3,3)}$ (us,g) & $\lambda_{t}^{(3,3)}$ (us, uk) & $\lambda_{t}^{(3,1)}(g, g)$ & $\lambda_{t}^{(3,1)}(\mathrm{uk}, \mathrm{uk})$ \\
\hline \multicolumn{6}{|l|}{ Ex post Excess Returns } \\
\hline Means & .074 & 3.431 & 1.808 & 0.105 & 0.035 \\
\hline Standard Deviations & 1.262 & 21.746 & 23.850 & 0.433 & 1.006 \\
\hline Correlations: $\lambda$ (us,us) & 1.000 & & & & \\
\hline$\lambda(u s, g)$ & -.314 & 1.000 & & & \\
\hline$\lambda(\mathrm{us}, \mathrm{uk})$ & -.149 & .492 & 1.000 & & \\
\hline$\lambda(g, g)$ & .230 & -.289 & -.089 & 1.000 & \\
\hline$\lambda(u k, u k)$ & .158 & -.016 & -.143 & .017 & 1.000 \\
\hline \multicolumn{6}{|l|}{ Ex ante Excess Returns } \\
\hline Means & .074 & 3.431 & 1.808 & 0.105 & 0.035 \\
\hline Standard Deviations & .518 & 9.776 & 12.590 & 0.210 & 1.133 \\
\hline Correlations: $\lambda$ (us,us) & 1.000 & & & & \\
\hline$\lambda(u s, g)$ & .108 & 1.000 & & & \\
\hline$\lambda(u s, u k)$ & -.102 & .490 & 1.000 & & \\
\hline$\lambda(g, g)$ & .210 & -.556 & .115 & 1.000 & \\
\hline$\lambda(\mathrm{uk}, \mathrm{uk})$ & .002 & -.289 & -.965 & -.270 & 1.000 \\
\hline
\end{tabular}

Sumary Statistics for Table 5 
TABLE 6

Latent Variable Estimates

(Based upon the five variable system in Table 5)

$\begin{array}{llll}\alpha_{0} & \begin{array}{c}-0.455 * \\ (.087)\end{array} & \beta_{1} & 1.000 \\ & (.000) & & \\ \alpha_{1} & \begin{array}{ll}0.704 * \\ (.072)\end{array} & & \\ & (.000) & \beta_{2} & -0.576 \\ & & & (1.593) \\ \alpha_{2} & 0.107 * & & (.718) \\ & (.018) & \beta_{3} & -2.094 \\ & (.000) & & (2.829) \\ \alpha_{3} & 0.023 & & (.459) \\ & (.013) & \beta_{4} & 1.011 * \\ & (.077) & & (.119) \\ \alpha_{4} & 0.399 * & & (.000) \\ & (.091) & & \\ & (.000) & 5 & 1.044 * \\ & & & (.145) \\ & & & \end{array}$

Correlations of estimated latent variable with instruments:

$\begin{array}{ll}R \text { (us) - R(us) } & 0.690 \\ R \text { (us) - R(ger) } & 0.600 \\ R \text { (us) - R(uk) } & 0.455 \\ \text { R(ger) - R(ger) } & 0.406 \\ \text { R(uk) - R(uk) } & 0.276\end{array}$

Value of $\chi^{2}(20): 14.489$; significance level: .805 . The initial values of the $\alpha^{\prime} s$ are the point estimates in the first row of Table 5; the initial values of thee $\beta^{\prime} s$ are unity. See note to Table 4. 
TABLE 7

Latent Variable Estimates

(Based upon a system comprised of first three rows of Table 5)

\begin{tabular}{|c|c|}
\hline$\alpha_{0}$ & $\begin{array}{r}-0.512 * \\
(.255) \\
(.045)\end{array}$ \\
\hline$\alpha_{1}$ & $\begin{array}{l}0.671 * \\
(.131) \\
(.000)\end{array}$ \\
\hline$\alpha_{2}$ & $\begin{array}{l}0.112 \\
(.061) \\
(.066)\end{array}$ \\
\hline$\alpha_{3}$ & $\begin{array}{l}0.011 \\
(.028) \\
(.694)\end{array}$ \\
\hline$\alpha_{4}$ & $\begin{array}{l}0.382 \\
(.361) \\
(.290)\end{array}$ \\
\hline$\alpha_{5}$ & $\begin{array}{r}-0.058 \\
(.091) \\
(.524)\end{array}$ \\
\hline$\beta_{1}$ & 1.000 \\
\hline$\beta_{2}$ & $\begin{array}{r}-0.501 \\
(2.867) \\
(.861)\end{array}$ \\
\hline$\beta_{3}$ & $\begin{array}{r}-1.933 \\
(4.455) \\
(.664)\end{array}$ \\
\hline
\end{tabular}

Correlations of estimated latent variable with instruments:

$\begin{array}{ll}R \text { (us) - R(us) } & 0.700 \\ R \text { (us) - R(ger) } & 0.595 \\ \text { R(us) - R(uk) } & 0.400 \\ \text { R(ger) - R(ger) } & 0.426 \\ \text { R(uk) - R (uk) } & 0.291\end{array}$

Value of $\chi^{2}(10): 13.539 ;$ significance level: .195. Initial values are as in Table 6 . See note to Table 4 . 


\section{FOOTNOTES}

1. However, as Hansen and Hodrick (1983) and Hodrick and Srivastava (1983) are careful to point out, their approach to modelling is best construed as an interpretation of a parsimonious statistical representation of risk premia using intertemporal capital asset pricing theory. In particular, their statistical tests are not tests of a fully specified equilibrium model.

2. Hodrick and Srivastava (1983) also employ non-overlapping data. However their rejection of the single latent variable model is not due to their different sample procedure.

3. We are grateful to Richard Levich for supplying us with these data, derived originally from Harris Bank sources. The data set also includes forward exchange rates and 6 and 12 month Eurodeposit interest rates, which we do not use here.

4. This approximation is commonly used in empirical work on the term structure (Shiller, Campbell and Schoenholtz (1983), Mankiw and Summers $(1984))$. For the short 3 -month holding period considered in this paper, the approximation is extremely accurate since gross returns are very close to one when measured in natural units.

5. Campbell and Shiller also discuss the "holding premium" on a long-term investment, sold before maturity, relative to a short-term investment. We do not consider holding premia in this paper since Eurodeposits are generally non-negotiable and must be held to maturity.

6. It would also be possible to arrange at time $t$ to convert the DM back to dollars at a known forward exchange rate. This would give a riskless 3 -month dollar return which by arbitrage ("covered interest parity") is always very close to the 3-month Eurodollar rate. Small deviations from covered interest parity in the Euromarkets appear to arise from transactions costs.

7. Note that it would not be possible to fully hedge the exchange risk of a mixed strategy by engaging in a forward exchange transaction. This is because the number of DM which must be converted back to dollars at time $t+3$ depends on future 1 -month DM rates, and thus is not known at time $t$.

8. By covered interest parity, the interest differential is also the forward premium ( 400 times the $\log$ of the ratio of the 3 -month ahead forward rate quoted at time $t$, to the time $t$ spot rate).

9. The decompositions of (17) and (18) help to account for the fact that spreads and differentials have been used to obtain powerful rejections of the expectations and Fisher open hypotheses, as documented in the introduction to the paper. 
10. All the information variables have a fairly high degree of serial correlation, so the standard deviations should not be interpreted as if they come from independently and identically distributed variables.

11. This statement is true for regressions with cross-currency excess returns (2) as the dependent variable. With term structure excess returns (1) or (3) as the dependent variable, uncertainty is resolved after 2 months when the 2 -month ahead 1 -month Eurodollar rate becomes known, so the error process is only MA-8. We ignore this in our empirical work, thus obtaining conservative estimates of standard errors.

12. Alternative methods for constructing a positive definite $\hat{\Omega}_{T}$ matrix have been developed by Hansen (1982) and Cumby, Huizinga and Obstfeld (1983). However we found Newey and West's approach to be easier to apply.

13. However, for all three excess return, we can rejects at the 58 level the hypothesis that the first six autocovariances are jointly zero.

14. Point estimates of some of the coefficients in Table 3 are sensitive to the starting values used in the estimation, because these starting values help to determine the first-round weighting matrix in the GMM procedure. However, the Chi-squared test statistic is only minimally affected by starting values. 
REFERENCES

Breeden, D. An Intertemporal Capital Asset Pricing Model with Stochastic Consumption and Investment Opportunities, Journal of Financial Economics, 7 (1979), 265-296.

Campbell, J. Stock Returns and the Term Structure, NBER Working Paper No. $1626,1985$.

and R. Shiller. A Simple Account of the Behavior of Long Term

Interest Rates, American Economic Review, 75 (1984), 44-48.

Cumby, R. Is It Risk? Explaining Deviating from Interest Parity, New York University, GSBA, October 1985.

, J. Huizinga, and M. Obstfeld. Two-Step, Two-Stage Least Squares Estimation in Models with Rational Expectations, Journal of Econometrics, 21, (1983), 333-355.

Cumby, R. and M. Obstfeld. A Note on Exchange Rate Expectations and Nominal Interest Differentials, Journal of Finance, 36 (1981), 697-704.

International 'Interest Rate and Price Level Linkages under Flexible Exchange Rates, in Bilson and Marston, eds., Exchange Rate Theory and Practice. Chicago: University of Chicago Press, 1984, pp. Fama, E. Forward and Spot Exchange Rates, Journal of Monetary Economics, 14
$(1984), 319-338$.

Geweke, J. and E. Feige. Some Joint Tests of Efficiency of Markets for Forward Foreign Exchange, Review of Economics and Statistics, 61 (1979), 334-341.

Gibbons, M. and W. Ferson. Testing Asset Pricing Models with Changing Expectations and an Unobservable Market Portfolio, Journal of Financial Economics, 14 (1985), 217-236.

Hakkio, C. Expectations and the Forward Exchange Rate, International Economic Review, 22 (1981a), 663-678.

The Term Structure of the Forward Premium, Journal of Monetary
Economics, 8 (1981b), 41-58.

and L. Leiderman. Intertemporal Asset Pricing and the Term Structure of Exchange Rates and Interest Rates, mimeo, Federal Reserve Bank of Kansas City, 1984. 
Hansen, L. The Asymptotic Distribution of Least Squares Estimators with Endogenous Regressors and Dependent Residuals, Carnegie-Mellon GSIA Working Paper, 1979.

Large Sample Properties of Generalized Method of Moments Estimators, Econometrica, 50 (1982), 1029-1054.

and R. Hodrick. Forward Exchange Rates as Optimal Predictors of Future Spot Rates, Journal of Political Economy, 88 (1980), 829-853.

- Risk Averse Speculation in the Forward Foreign Exchange Market, in J. Frenkel (ed.), Exchange Rates and International Macroeconomics. Chicago: University of Chicago Press, 1983, pp. 115-152.

Hansen, L. and S. Richard. Characterizing Asset Pricing under Value Additivity, Carnegie-Mellon GSIA Working Paper, 1983.

Hansen, L., S. Richard, and K. Singleton. Econometric Implications of the Intertemporal Capital Asset Pricing Model, unpublished Carnegie GSIA Discussion Paper, November 1981.

Hansen, L. P. and K. Singleton. Generalized Instrumental Variables Estimation in Nonlinear Rational Expectations Models, Econometrica, 50 (1982), 1269-1286.

Hodrick, R. J. and S. Srivastava. An Investigation of Risk and Return in Forward Foreign Exchange, Journal of International Money and Finance, 3 (1984), 5-29.

Hsieh, D. Tests of Rational Expectations and No Risk Premium in Forward Foreign Exchange Markets, Journal of International Economics, 17 $(1984), 173-184$.

Lucas, R. Asset Prices in an Exchange Economy, Econometrica, 46 (1978), $1429-1446$.

Interest Rates and Currency Prices in a Two-Country World, Journal of Monetary Economics, 10 (1982), 335-359.

Mankiw, N. G. and I. Summers, Do Long-Term Interest Rates overreact to Short-Term Interest Rates? Brookings Papers on Economic Activity, 1 (1984), 223-242.

Mark, N. On Time-Varying Risk Premia in the Foreign Exchange Market: An Econometric Analysis, Journal of Monetary Economics, 16 (1985), 3-18.

Merton, R. An Intertemporal Capital Asset Pricing Model, Econometrica, 44 (1973), 867-887. 
Newey, W. and K. West. A Simple, Positive Definite, Heteroskedasticity and Autocorrelation Consistent Covariance Matrix, Woodrow Wilson School Discussion Paper No. 92, Princeton University, 1985.

Shiller, R., J. Campbell and K. Schoenholtz. Forward Rates and Future Policy: Interpreting the Term Structure of Interest Rates, Brookings Papers on Economic Activity, 1 (1983), 173-217.

White, H. Asymptotic Theory for Econometricians. Orlando: Academic Press, 1984 . 